\title{
К ВОПРОСУ О ПАРЕМИЯХ В РОМАНАХ АЛЕКСАНДРА ПРОХАНОВА
}

Акимова К. Г. До питання про паремії в романах Олександра Проханова.

Статтю присвячено характеру використання паремій у мові романів сучасного письменника Олександра Проханова. Розглянуто особливості функціонування в художніх текстах як узуальних прислів’їв і приказок, так і оказіональних усталених фраз, створених письменником з певною метою.

Ключові слова: паремія, прислів’я, приказка, усталена фраза, фразеологічна одиниця, узуальна, оказіональна.

Акимова Е. Г. К вопросу о паремиях в романах Александра Проханова.

Статья посвящена характеру употребления паремий в языке романов современного писателя Александра Проханова. Рассматриваются особенности функционирования в художественных текстах как узуальных пословиц и поговорок, так и окказиональных устойчивых фраз, создаваемых писателем с определенными целями.

Ключевые слова: паремия, пословица, поговорка, устойчивая фраза, фразеологическая единица, узуальная, окказиональная.

Akimova E. G. To the question of proverbs in the novels of Alexander Prokhanov.

The article is devoted to the character of proverbs using in the language of the modern writer Alexander Prokhanov's novels. The author of the article considers features of functioning in fiction both usual proverbs and sayings, and the occasional steady phrases, created by the writer with the definite purposes.

Key words: proverbs, sayings, a stable phrase, praseological unit, usual, occasional.

Устойчивые фразы в языке художественной прозы современного писателя А. Проханова представлены двумя пластами: во-первых, пословицами и поговорками, во-вторых, крылатыми выражениями. Пословицы и поговорки, объединенные в паремии, становятся объектом нашего исследования.

Под паремиями понимаются «вторичные языковые знаки - замкнутые устойчивые фразы (пословицы и поговорки), являющиеся маркерами ситуаций или отношений между реалиями. Они привлекают носителей языка своей семантической ёмкостью и способностью к употреблению в различных речевых ситуациях и с разными речевыми целями» [10, с. 3].

В филологии существует множество определений пословицы и поговорки. В качестве рабочих мы берем определения, выведенные и сформулированные Л. Савенковой. Пословица - «устойчивое в языке и 
воспроизводимое в речи анонимное обобщающее изречение, хотя бы часть элементов которого наделена переносным значением и которое пригодно к использованию в дидактических целях» [11, с. 67]. Поговорка - «устойчивое в языке и воспроизводимое в речи анонимное обобщающее изречение, лишенное переносности значения и пригодное для употребления в дидактических целях» [там же].

Паремии в языке А. Проханова нередко подвергаются различным трансформациям. Особый вид семантического варьирования - двойная актуализация, при которой «соответствующий буквальному плану денотат, послуживший поводом для языкового обыгрывания, получает в тексте двойное осмысление - в конкретно-прямом и обобщенно-переносном значениях», как бы вложенных, по определению В. Бондаренко, «друг в друга» [1, с. 39]. Так, пословица Не спросясь (не зная) броду, не суйся в воду, употребляемая в речи в значении «не предпринимай чего-либо без знания дела. Говорится тому (или о том), кто, делая что-либо, из-за неосведомленности, незнания терпит неудачу» [5, с. 221] в контексте романа А. Проханова получает совмещение смыслов. Например: Тем временем далеко от стройки, медленно к ней приближаясь, по пустынной и скользкой дороге, мимо редких деревьев и занесенньх снегом опушек, ехал автобус. $\langle\cdots\rangle-$ B вь везете в Броды подарок? - Она [Антонина - Е. А.] посмотрела на его [Фотиева] старый портфель. - Вот здесь? (‥) В Бродах трудно чем-нибудь удивить... Может быть, вы не на станцию? Просто в город? Учителем литературы, истории? - Да нет, я не учитель. Хотя действительно недавно прочитал несколько исторических книг. Историю этих мест полистал. Захотелось узнать, кто эти Броды закладывал. Кто здесь брёл до меня. А то говорят: «Не зная броду, не суйся в воду!» [7, с. 53]. В данном случае мы наблюдаем пример двойной актуализации: с одной стороны, употребление в речи героем романа Фотиевым пословицы подтверждает, что он едет в новые, неизвестные ему места, а с другой стороны, лексический компонент в составе пословицы Не зная броду, не суйся в воду - «брод», омонимичный названию населенного пункта, куда собирается Фотиев, - «Броды», - служит конкретизатором смысла пословицы: в населенном пункте с названием Броды «не предпринимай чего-либо без знания дела».

В языке А. Проханова употребляются и окказиональные паремии. Среди них особое место занимают единицы, построенные по аналогии с известными пословицами, с сохранением рифмы, но являющиеся в творчестве писателя окказиональными.

Ряд выражений в речи героев А. Проханова образован по $-239-$

(с Е. Г. Акимова, 2015. 
синтаксической модели пословиц, в частности, реализуя принцип контраста. Контраст репрезентирует «дихотомическое восприятие мира и предмета речи, создающий или воспроизводящий дуальную модель действительности». В таком случае, по мнению Т. Бочиной, мы наблюдаем «взаимодействие различных точек зрения», своеобразный диалог: «в диалогической сути контраста, его полемической основе коренится особая значимость данного принципа развертывания речи для организации и функционирования пословицы, являющейся обобщенным результатом филогенетического диалога между прошлым, настоящим и будущим. Оппозитивная пословица представляет собой резюме диахронического диалога, свернутого в риторический монолог, что объясняет коммуникативную активность пословицы, ее предназначенность служить строевым элементом текста, репликой в диалоге» [2, с. 11]. Например, «OKO» хорошо, а дело лучше в следующем контексте: Вошел [Горностаев Е. А.] в кабинет, где поджидала его горячая желанная чашечка кофе, усмехнулся: “ОКО» хорошо, а дело лучше [7, с. 230]. В словах героя скрывается злая усмешка по отношению к новой теории повышения эффективности производства, именуемой «ОКО». Исходной структурой, по модели которой построен рассматриваемый вариант, можно считать пословицу Одна голова хорошо, а две лучше. При этом следует говорить о замене лексического компонентов «одна голова» и «две» на «ОКО» и «дело» соответственно. Однако не все из образованных А. Прохановым устойчивых фраз имеют известный «прототип». Поэтому, на наш взгляд, правильнее будет говорить о тождестве синтаксических моделей, по которым данные устойчивые фразы построены, своеобразных структурных формул. Так, единица Ecmь почин, а есть кончин построена на основе антитезы. О распространенности среди узуальных пословиц подобной модели пишет Т. Бочина: «Характерная для антитезы двучленная структура определяет распространенность в пословицах и поговорках конструкций, где противопоставляются и темы, и ремы антитетического высказывания: Умереть легко, а жить трудно; Ничего нельзя, а все молено; Старое проживай, а новое наживай! Грамматический параллелизм, сходство синтаксических структур подчеркивают, делают еще более контрастной противоположность, выраженную лексическими средствами» [2, с. 7].

Целый ряд русских пословиц построен по рифмованным моделям: Мирская молва что морская волна; Рыбак рыбака видит издалека; Черного кобеля не отмоешь добела; Мороз не велик, да стоять не велит и др. Ср. у А. Проханова: Белосельчев очнулся... Протянув к огню скрюченные черныле пальцы, стоял человек. Мохнатый, заросший до бровей клочковатой С Е. Г. Акимова, 2015. 
шерстью, в драных одеждах, он был похож на лесовика, вылезшего из-под коряги... Белосельцев слушал его невнятное бормотание. Дорожил его присутствием, как последним, вместе с ним уцелевиим на земле существом, с которым теперь предстояло доживать свой век... - Он говорит - Боря, а я говорю - буря!.. Потому что борется, так что бор ломится!.. Потому Боря, что бурый, а не каурый! - человечек задумался...[6, с. 469]. В том же романе Они [Белосельцев и Катя - Е. А.] проснулись одновременно... Здравствуй, - сказала она [Катя] - Пора подниматься, за дело приниматься. - Дело-то у нас какое? - Он ульбнулся, обнимая ее под одеялом. - Встанем, оглядимся. Глядишь, и дело найдется! [6, с. 434].

В другом романе, «Скорость тьмы», при проведении мероприятий, посвященных Дню города, гражданам бесплатно раздавались пакетики «с порцией водки»: На пакетиках было начертано затейливое нравоучение: «Знай меру, доверяй мэру!». К пакетику прилагались чипсы и недорогие, но вкусные соевые батончики [8, с. 383]. Все эти окказиональные единицы образованы на основе рифмы. «Услышав такую пословицу однажды, невозможно не запомнить ее на всю жизнь, и не отдельными словами, а так, как есть, целым слитком слов. Рифма придает дополнительную магическую власть незабываемости. Афоризм становится музыкой» [4]. Что касается последней единицы Знай меру, доверяй мэру, то еe можно сравнить с узуальной паремии, зафиксированной в «Словаре русских пословиц и поговорок» В. Жукова, - Знай край, да не падай в значении «знай меру, не переходи границ дозволенного» [5, с. 127]. Если соотнести смысловое наполнение первой и второй частей сложного предложения, по модели которого построены данные узуальная и окказиональная устойчивая фраза, то можно сделать вывод о скрытой иронии А. Проханова в отношении к «затейливому нравоучению» про доверие к мэру. Скорее всего, правильнее «знать меру», но не доверять мэру (Ср.: нужно «знать край», но не падать). Окказиональные устойчивые фразы А. Проханова часто по форме близки к афоризмам. Афоризмом называется «изречение, выражающее с предельной лаконичностью в отточенной форме какую-либо оригинальную мысль» [12, с. 289].

Показательным с точки зрения образования окказиональных устойчивых фраз по модели афоризмов, следует считать диалог двоих друзей в романе «Скорость тьмы». Ср.: - Чтобы не уnасть, надо лететь, - возгласил в телефонной трубке голос друга. - Хочешь лететь, создавай небо, - мгновенно отозвался Ратников, вспоминая афоризмы из созданного ими ичитатника. - Если упал, сразу взлетай. - Лучше быть пятном на 
солнце, чем кратером на луне. - Рай - это Рублев, помноженный на скорость света. - Ад - это Босх, помноженный на скорость тьмы. Один плюс один равняется бесконечность. - Дружба - не арифметика, а геометрия Лобачевского. - Подлетая к черной дыре, застегни привязные ремни [8, с. 119]. Все выделенные единицы являются окказиональными, индивидуально-авторскими афоризмами, принадлежащими перу А. Проханова. Целый ряд из этих приведенных единиц построен по модели контраста, о которой говорилось выше. В данном случае этот контраст реализуется, во-первых, посредством контекстуальных антонимических пар в структуре устойчивой фразы (упасть - лететь, солнце - луна, рай-ад). Ср. узуальные паремии: Давши слово, держись, а не давщи, крепись; Дорого, да мило, дешево, да гнило; Дружно - не грузно, а врозь - хоть брось [5]. Во-вторых, в структуре сложного предложения раскрываются различные обстоятельственные отношения явлений (Хочешь лететь, создавай небо; Если упал, сразу взлетай; Подлетая к черной дыре, застегни привязнье ремни). Ср. с узуальными паремиями: $C$ глаз долой - из сердиа вон; $C$ кем поведешься, от того и наберешься; Сам кашу заварил, сам и расхлебывай; Пешком ходить - долго жить; Где тонко, там и рвется. В-третьих, некоторые устойчивые фразы построены по модели дефиниции (лат. definitio определение) - логической операции, выраженной в следующей структуре: дефиниендум (определяемое имя) и дефиниенс (определяющее выражение, раскрывающее смысл определяемого имени либо устанавливающее значение термина). Ср. окказиональные единицы: Дружба - не арифметика, а геометрия Лобачевского; Рай - это Рублев, помноженный на скорость света. - Ад - это Босх, помноженный на скорость тьмы и узуальные паремии: Мужик в семье что матица в избе; Муж да жена одна сатана; Риск - благородное дело; Старость не радость.

Разумеется, считать выделенные нами единицы в полной мере фразеологизмами нельзя, но обратить внимание на их существование в романе А. Проханова необходимо, так как они играют важную роль в раскрытии взаимоотношений героев романа: совместное создание цитатника афоризмов с глубоким философским смыслом характеризует их как хороших друзей и людей с особым философским складом ума и души.

Известная пословица И волки cblmbl, и овцы целы употребляется в значении: «и для одних, и для других удобно, выгодно. О положении, которое создается в результате стремления угодить людям с различными взглядами, интересами и т. п.» [5, с. 129]. В. Даль связывает значение этой пословицы с понятиями «прямоты-лукавства» [3]. Авторскими (․Е.Г. Акимова, 2015. 
трансформациями и синонимами исходной пословицы являются окказиональные единицы Коза сыта и капуста цела; Капитал приобрести и невинность соблюсти. Две части предложения, соединенные повторяющимся союзом $u$ в исходном варианте и одиночным союзом - в трансформации, подразумевают двуличие человека. На основе замены компонентов, как результат лексического варьирования, в романе «Господин Гексоген» рождается индивидуальноавторские фразеологические единицы: - Теперь и белки сыты, и пчелки здравы, - произнес Николай Николаевич, удовлетворенный сделанными покупками. - Теперь и мы в силе, и Бог во славе! - добавил он, увлекая Белосельцева к своему экипажу [9, с. 121].

Паремии в текстах А. Проханова выполняют стилеобразующую функцию, отражая на фразеологическом уровне своеобразие авторского стиля, особенности языковой личности писателя. Употребление героями А. Проханова в речи разнообразных народных пословиц и поговорок помогает создать яркие образы этих персонажей через их речевую характеристику.

\section{Литература}

1. Бондаренко В. Т. Устойчивые фразы в русской речи : [монография] В. Т. Бондаренко. - Тула : Изд-во Тул. гос. пед. ун-та им. Л. Н. Толстого, 2011. - 153 с.

2. Бочина Т. Г. Контраст как лингвокогнитивный принцип русской пословицы : дис. ... д-ра филол. наук / Т. Г. Бочина. - Казань, 2003.

3. Даль В. И. Пословицы русского народа / В. И. Даль. - М. : Художественная литература, 1989.

4. Євтушенко Е. Рифмованные пословицы [Электронный ресурс] / Е. Евтушенко. - 15.09.2005. - Режим доступа : http://www.newizv.ru

5. Жуков В. П. Словарь русских пословиц и поговорок / В. П. Жуков. - М., 1991. $-538 \mathrm{c}$.

6. Проханов А. А. Красно-коричневый. Роман / А. А. Проханов // Собрание починений : в 15-и тт. - Т. 5. - М. : Книжный Клуб Книговек, 2010. - С. 7-700.

7. Проханов А. А. ОКО / А. А. Проханов. - М. : Амфора, 2010. -670 с.

8. Проханов А. А. Скорость тьмы. Роман / А. А. Проханов // Собрание починений : в 15-и тт. - Т. 15. - М. : Книжный Клуб Книговек, 2010. - С. 7-424.

9. Проханов А. А. Господин Гексоген. Роман / А. А. Проханов // Собрание починений : в 15-и тт. - Т. 6. - М. : Книжный Клуб Книговек, 2010. - С. 7-700.

10. Савенкова Л. Б. Русские паремии как функционирующая система : автореф. дис. ... д-ра филол. наук / Л. Б. Савенкова. - Ростов н/Д, 2002. - 46 с.

11. Савенкова Л.Б. Русская паремиология : семантический и лингвокультурологический аспекты /Л. Б. Савенкова. - Ростов н/Д, 2002. - 240 с.

12. Словарь русского языка : в 4-х т. / Под ред. А. П. Евгеньевой. - РАН, Ин-т лингвистических исследований. - [4-е изд., стер.]. - М. : Русский язык; Полиграфресурсы, 1999.

Стаття надійшла до редакиії 28.06.2015 p. 